\title{
PENERAPAN METODE KOOPERATIF TIPE TAI (TEAM ASSISTED INDIVIDUALIZATION) PADA MATERI PERSAMAAN LINEAR DUA VARIABEL UNTUK MENINGKATKAN HASIL BELAJAR SISWA KELAS X-IPA SMA METHODIST BANDA ACEH
}

\author{
Eliudin Gea, S.Pd
}

\begin{abstract}
ABSTRAK
Tujuan penelitian ini adalah untuk meningkatkan hasil belajar siswa kelas X-IPA SMA Methodist Banda Aceh dengan menerapkan metode kooperatif tipe Team Assisted Individualization (TAI) pada Materi Persamaan Linier Dua Variabel. Penelitian ini merupakan Penelitian Tindakan Kelas (PTK) dengan prosedur pelaksanaannya melalui tahapan: perencanaan, pelaksanaan tindakan, pengamatan, dan refleksi. Penelitian ini dilaksanakan pada semester ganjil tahun pelajaran 2018/2019. Subjek dalam penelitian ini adalah siswa kelas kelas X-IPA SMA Methodist Banda Aceh yang berjumlah 17 orang. Teknik pengumpulan data melalui observasi, tes dan dokumentasi. Data dilakukan analisis dengan cara deskriptif kualitatif. Hasil penelitian menunjukkan bahwa: (1) ketuntasan hasil belajar siswa secara klasikal pada kondisi awal adalah 58,8\%. Pada siklus I, ketuntasan siswa meningkat $17,7 \%$ dari sebelumnya sehingga mencapai $76,5 \%$ sehingga ketuntasan belajar secara klasikal dapat dikatakan tidak tuntas. Pada siklus ke II terjadi peningkatan ke arah yang lebih baik lagi dan meningkat 23,5\% sehingga mencapai $100 \%$. Maka dapat disimpulkan bahwa Penerapan Metode Kooperatif Tipe Team Assisted Individualization (TAI) pada Materi Persamaan Linier Dua Variabel dapat Meningkatkan Hasil Belajar Siswa Kelas X-IPA SMA Methodist Banda Aceh.
\end{abstract}

Kata Kunci: Metode Kooperatif Tipe Team Assisted Individualization (TAI), Materi Persamaan Linier Dua Variabel, dan Hasil Belajar Siswa

\section{PENDAHULUAN}

Matematika merupakan dasar dari semua proses ilmu berhitung baik pelajaran fisika, kimia dan lain-lain. Dalam pembelajaran matematika terdapat berbagai permasalahan yang berhubungan dengan kehidupan sehari-hari. Oleh karena itu, siswa dituntut memiliki kemandirian belajar khususnya dalam setiap memecahkan masalah-masalah yang berhubungan dengan mata pelajaran matematika. Tujuan diajarkannya mata pelajaran Matematika pada tingkat Sekolah Menengah Atas (SMA) adalah untuk memahami konsep-konsep matematika, menjelaskan keterkaitan antar konsep dan mengaplikasikan konsep, secara akurat, efisien, dan tepat dalam pemecahan masalah (Hudoyo, 2006: 346).

Belajar matematika merupakan suatu bentuk pembelajaran menggunakan bahasa simbol dan membutuhkan penalaran serta pemikiran yang logik dalam pembentukannya. Dalam pembelajaran matematika, guru hendaknya menggunakan model pembelajaran yang dapat mengaktifkan siswa baik sendiri maupun berkelompok. Prinsip belajar aktif inilah yang diharapkan dapat menumbuhkan sasaran pembelajaran matematika yang efektif. Sudjana (2010:60) mengemukakan bahwa "Kreativitas guru sangat penting untuk mengembangkan model-model pembelajaran yang secara khusus cocok dengan kelas yang dibinanya termasuk sarana prasarananya yang mendukung terjadinya optimalisasi interaksi semua unsur pembelajaran."

Salah satu materi yang berhubungan dengan masalah dalam kehidupan seharihari adalah materi persamaan linier dua variabel. Materi ini diajarkan terhadap siswa kelas X-IPA SMA Methodist Banda Aceh 
pada semester ganjil tahun ajaran 2018/2019. Pembelajaran materi ini pada siswa bertujuan untuk; (1) siswa dapat memahami penerapan persamaan linier dua variabel dalam kehidupan sehari-hari, dan (2) siswa dapat menyelesaikan penerapan persamaan linier dua variabel dalam kehidupan sehari-hari dengan metode eliminasi dan subtitusi.

Hasil observasi peneliti pada kelas X-

IPA SMA Methodist Banda Aceh menunjukkan bahwa tujuan yang diharapkan dari materi ini tidak mampu dicapai oleh seluruh siswa kelas X-IPA. Saat pembelajaran berlangsung ketika peneliti (guru) menyajikan bahan melalui penjelasan lisan secara langsung terhadap siswa dan melakukan tanya jawab mengenai materi yang telah dijelaskan, banyak siswa belum mampu memahami materi yang diajarkan. Pengamatan peneliti saat siswa kesulitan memahami materi secara berkelompok, tidak semua siswa serius untuk mengerjakannya, sehingga siswa yang lain hanya menunggu hasil. Akibatnya ketika diberikan tes, hasil belajar siswa banyak yang belum mencapai nilai $\geq 70$ (nilai KKM matematika untuk materi persamaan linier dua variabel). Dari 17 siswa, hanya 10 siswa yang tuntas atau $58,8 \%$ dengan nilai ratarata 70 . Padahal jumlah siswa tuntas yang diharapkan adalah $\geq 85 \%$. Hasil ini tentu belum mencapai indikator keberhasilan yang telah ditetapkan dalam KKM sekolah pada pelajaran matematika.

Hasil pengamatan dan diskusi dengan rekan sejawat, pembelajaran konvensional yang dilakukan oleh peneliti menjadikan guru satu-satunya pusat perhatian. Sehingga proses belajar mengajar lebih banyak didominasi oleh guru. Akibatnya partisipasi siswa dalam proses belajar mengajar relatif kecil. Schoenfeld (Yuwono, 2005:2) mengemukakan bahwa pengajaran matematika secara konvensional mengakibatkan peserta didik hanya bekerja secara prosedural dan memahami matematika tanpa penalaran. Selain itu, Hamalik (2008:57) juga menyatakan bahwa salah satu kelemahan metode ceramah adalah ingatan yang diperoleh dengan cara mekanis akan segera mudah dilupakan.

Sebagai salah satu upaya untuk meningkatkan hasil belajar siswa dalam mencapai ketuntasan minimal yang telah ditetapkan pada materi persamaan linier dua variabel, rekan sejawat menyarankan agar peneliti melakukan perbaikan metode mengajar dari konvensional kepada pembelajaran yang bersifat siswa aktif. Pengamat juga menyarankan kepada peneliti untuk menggunakan pembelajaran kooperatif, karena dengan pembelajaran kooperatif ini siswa akan bekerjasama dan saling membantu dalam menghadapi permasalahan yang diberikan oleh guru.

Sebagai upaya untuk meningkatkan hasil belajar siswa materi sistempersamaan linier dua variabel, peneliti menerapkan metode kooperatif tipe Team Assisted Individualization (TAI). Dengan penerapan metode kooperatif tipe TAI menjadikan suasana kelas menjadi aktif saat belajar, guru hanyalah menjadi fasilitator, motivator dan mediator. Sedangkan siswa adalah pemeran utama yang harus merasa terlibat secara langsung dalam proses pembelajaran. Dengan demikian, harapannya hasil belajar siswa dapat meningkat.

Hasil belajar merupakan kemampuan yang diperoleh individu setelah proses belajar berlangsung, yang dapat memberikan perubahan tingkah laku baik pengetahuan, pemahaman, sikap dan keterampilan mahasiswa sehingga menjadi lebih baik dari sebelumnya. Menurut Sudjana (2010:3) bahwa "hasil belajar ialah perubahan tingkah laku yang mencakup bidang kognitif, afektif, dan psikomotor yang dimiliki siswa setelah menerima pengalaman belajarnya".

Pemilihan pembelajaran kooperatif Team Assisted Individualization (TAI) dalam kegiatan belajar mengajar dimaksudkan untuk membatasi keterlibatan guru dalam pemeriksaan dan pengelolaan rutin, belajar melakukan kerja sama dengan kelompok belajar, meningkatkan aktivitas belajar siswa dalam kegiatan belajar mengajar dalam, sebuah tim, meningkatkan partisipasi 
siswa untuk dapat menguasai materi dengan cara mengelola kemampuan individualnya dalam sebuah tim dan memotivasi siswa untuk mempelajari materi yang diberikan dengan cepat dan akurat, dan tidak akan bisa berbuat curang atau menyelesaikan dengan jalan pintas (Ibrahim, 2007:10)

Pendapat di atas menunjukkan bahwa Model pembelajaran kooperatif tipe TAI merupakan strategi pembelajaran yang berpusat pada siswa (student centered). Pada model pembelajaran kooperatif ini, siswa biasanya belajar menggunakan LKS (lembar kerja siswa) secara berkelompok. Siswa kemudian berdiskusi untuk menemukan atau memahami konsep-konsep. Setiap anggota kelompok dapat mengerjakan satu persoalan (soal) sebagai bentuk tanggungjawab bersama. Penerapan model pembelajaran kooperatif TAI lebih menekankan pada penghargaan pertanggungjawaban individu dan memperoleh kesempatan yang sama untuk berbagi hasil bagi setiap anggota kelompok.

Hasil penelitian yang dilakukan oleh Hermawan, dkk (2012) menyimpulkan bahwa Penerapan model pembelajaran kooperatif tipe Team Assisted Individualization (TAI) dapat meningkatkan hasil belajar siswa. Hasil penelitian Karim \& Anshariyah (2016) menyimpulkan bahwa model pembelajaran kooperatif tipe TAI dapat melatih kemampuan pemecahan masalah matematis siswa. Hasil penelitian Rahmawati, dkk (2017) menyimpulkan bahwa ada pengaruh penggunaan model pembelajan kooperatif tipe Team Assistead Individualization (TAI) terhadap hasil belajar siswa. Hasil penelitian Sari, dkk (2018) menyimpulkan bahwa penerapan model pembelajaran kooperatif TAI dilengkapi LKS dapat meningkatkan kemampuan berpikir kritis dan prestasi belajar siswa.

Beberapa hasil penelitian di atas menunjukkan bahwa penerapan model pembelajaran kooperatif Team Assisted Individualization (TAI) dapat meningkatkan kemampuan berpikir kritis siswa, dapat meningkatkan hasil belajar dan prestasi belajar siswa, dan dapat meningkatkan kemampuan pemecahan masalah matematis siswa.

Berdasarkan uraian di atas, maka peneliti tertarik untuk melakukan penelitian tindakan kelas secara mendalam dengan judul "Penerapan Metode Kooperatif Tipe TAI (Team Assisted Individualization) pada Materi Persamaan Linier Dua Variabel untuk Meningkatkan Hasil Belajar Siswa Kelas X-IPA SMA Methodist Banda Aceh". Tujuan penelitian ini adalah untuk meningkatkan hasil belajar siswa kelas XIPA SMA Methodist Banda Aceh dengan menerapkan metode kooperatif tipe Team Assisted Individualization (TAI) pada Materi Persamaan Linier Dua Variabel.

\section{METODE PENELITIAN}

Penelitian ini merupakan penelitian tindakan kelas (PTK). Penelitian Tindakan Kelas adalah suatu pendekatan untuk memperbaiki pendidikan melalui perubahan, dengan mendorong para guru untuk memikirkan praktik mengajarnya sendiri, agar kritis terhadap praktik tersebut dan agar mau untuk mengubahnya. PTK mendorong guru untuk berani bertindak dan berpikir kritis dalam mengembangkan teori dan rasional bagi mereka sendiri, dan bertanggung jawab mengenai pelaksanaan tugasnya secara profesional (Hardjodipuro, 2014:20). Dalam penelitian PTK menggunakan dan mengembangkan siklus yang mengandung empat komponen yaitu: (1) rencana tindakan (planning), (2) pelaksanaan (action), (3) observasi (observation), (4) refleksi (reflection). Adapun gambaran tahap penelitian menurut Suyadi (2012:50) adalah sebagai berikut:

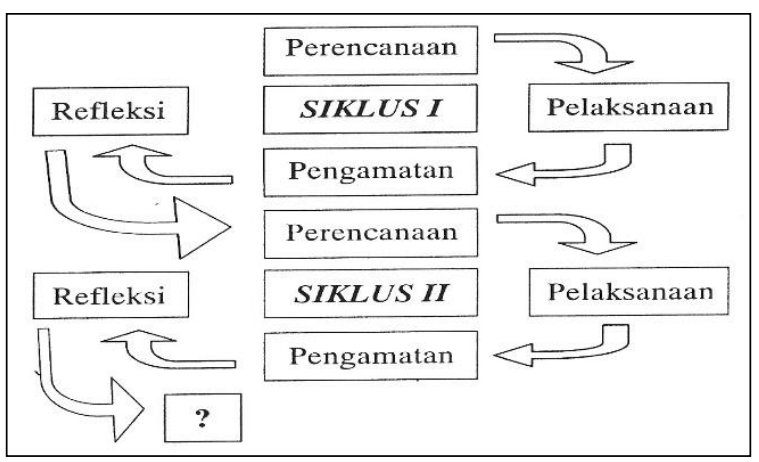


Penelitian ini dilakukan di SMA Methodist Banda Aceh pada semester ganjil tahun pelajaran 2018/2019. Penelitian dilaksanakan selama tiga bulan yaitu mulai dari bulan Agustus 2018 sampai dengan September 2018. Subjek dalam penelitian ini adalah siswa kelas kelas X-IPA SMA Methodist Banda Aceh pada tahun pelajaran 2018/2019 yang berjumlah 17 orang yang terdiri dari 8 siswa dan 9 siswi.

Teknik pengumpulan data dilakukan dengan cara observasi, tes dan dokumentasi. Observasi dipandu dengan lembar pengamatan yang dilakukan dengan bantuan rekan sejawat untuk memperoleh data tentang aktivitas guru dan aktivitas belajar siswa. Tes diberikan secara tertulis dalam bentuk uraian untuk mengetahui sejauh mana siswa menguasai materi persamaan linear dua variabel. Teknik dokumentasi dilakukan untuk mengumpulkan data tentang silabus, rencana pelaksanaan pembelajaran (RPP) dan nilai siswa sebelum dan sesudah diterapkan model pembelajaran kooperatif tipe TAI dan semua dokumen yang berhubungan dengan penelitian.

Analisis data dilakukan dengan cara melihat ketuntasan secara individual dan klasikal. Ketuntasan hasil belajar siswa secara individual akan dilakukan persentasi secara klasikal dengan menggunakan rumus persentase, yaitu:

$$
\mathrm{P}=\frac{\text { Jumlah siswa yang tuntas }}{\text { jumlah siswa keseluruhan }} X 100 \%
$$

Penerapan model pembelajaran TAI pada materi sistem persamaan linear dua variabel dikatakan berhasil apabila hasil belajar siswa secara individu dikatakan tuntas apabila $\geq 70$ dari skor total hasil tes. Sedangkan untuk ketuntasan belajar secara klasikal apabila $\geq 85 \%$ siswa di kelas tersebut telah tuntas belajar.

\section{HASIL PEMBAHASAN}

$\begin{array}{cccr}\text { Pada } & \text { kondisi } & \text { awal } & \text { sebelum } \\ \text { menerapkan } & \text { model } & \text { TAI, } & \text { peneliti }\end{array}$ menemukan beberapa permasalahan yang ada didalam kelas serta dikatakan bahwa kegiatan belajar mengajar di kelas masih belum optimal sehingga mengakibatkan hasil belajar siswa masih tergolong rendah. Menurut peneliti yang perlu ditingkatkan adalah metode pembelajaran yang mengarahkan siswa menjadi aktif. Pola pembelajaran yang lebih mengutamakan ceramah, monoton/statis, dan terkesan hanya mengejar materi pelajaran tanpa mempertimbangkan proses pembelajaran. Oleh karena itu, peneliti mengadakan diskusi lebih lanjut dengan guru lain (pengamat) untuk mengatasi permasalahan yang muncul tersebut dengan menerapkan metode pembelajaran kooperatif tipe TAI.

Dalam pelaksanaan siklus I, sebelum guru menyampaikan materi kepada siswa terlebih dahulu guru perlu membangkitkan minat dan semangat siswa untuk mengikuti kegiatan belajar mengajar yang akan dilakukan. Setelah guru mempresentasikan materi kemudian pada pertemuan selanjutnya guru masih mempresentasikan materi kemudian siswa diberi soal latihan individu. Kemudian siswa ditempatkan kedalam kelompok-kelompok yang telah ditentukan masing-masing keompok 4-5 orang, untuk membahas lembar kegiatan atau latihan individu yang diberikan oleh guru secara berkelompok. Kemudian siswa diberi kesempatan untuk mempresentasikan hasil diskusi kelompoknya di depan kelas, selanjutnya diadakan kuis perkembangan untuk mengetahui seberapa jauh pemahaman siswa setelah bekerja dalam kelompok belajarnya.

Hasil observasi terhadap pelaksanaan tindakan pada siklus I, masih terdapat beberapa kelemahan dan kekurangan baik dari sisi guru maupun siswa. Guru kurang menguasai kelas khususnya siswa yang duduk dibagian belakang kurang mendapat perhatian khusus dari guru sehingga banyak dari mereka yang melakukan aktifitasaktifitas yang tidak perlu. Selain itu kurangnya motivasi yang diberikan oleh guru untuk membangkitkan minat dan semangat siswa untuk mengikuti pelajaran. Sedangkan dari sisi siswa adalah masih kurang aktifnya siswa dalam mengikuti proses pembelajaran dikelas baik itu 
kegiatan belajar mengajar maupun pada saat diskusi kelompok. Oleh karena itu, peneliti mencari solusi yang tepat untuk mengatasi kelemahan dan kekurangan yang muncul dari kegiatan belajar mengajar pada siklus I tersebut dan akan diperbaiki dalam pelaksanaan kegiatan belajar mengajar pada siklus II.

Pada sikus II ini para siswa sudah mulai terlihat aktif dalam mengikuti kegiatan belajar mengajar maupun diskusi kelompoknya. Siswa sudah dapat memanfaatkan dengan baik kegiatan diskusi kelompok untuk membahas materi pelajaran yang belum dkuasainya dengan teman satu kelompoknya. Berdasarkan hasil pengamatan terhadap kegiatan belajar mengajar pada siklus II, dapat dikatakan bahwa prestasi belajar serta keaktifan siswa telah mengalami peningkatan, dan nilai yang diperoleh telah memenuhi indikator ketercapaian yang sudah ditetapkan guru kelas.

Hasil belajar siswa dapat dilihat dari tes yang diberikan pada akhir pertemuan. Tes yang diberikan berbentuk essay yang berjumlah 5 soal setiap siklus, hasil belajar yang diharapkan adalah siswa dapat menyelesaikan soal soal tersebut dengan baik. Adapun hasil belajar siswa dapat dilihat pada gambar grafik di bawah ini.

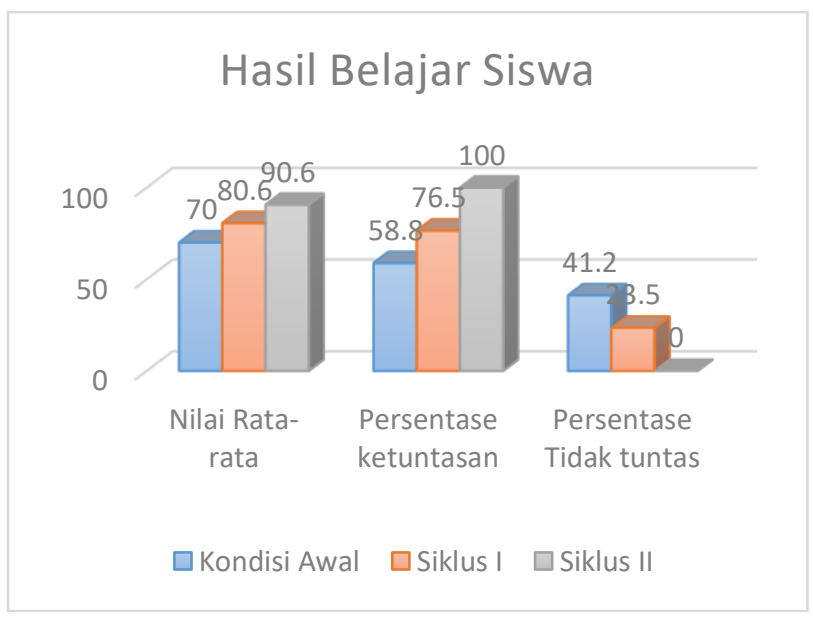

Pada grafik di atas terlihat bahwa pada kondisi awal, ketuntasan siswa hanya $58,8 \%$. Pada siklus I, ketuntasan siswa meningkat $17,7 \%$ dari sebelumnya sehingga mencapai 76,5\% sehingga ketuntasan belajar secara klasikal dapat dikatakan tidak tuntas. Pada siklus ke II terjadi peningkatan ke arah yang lebih baik lagi dan meningkat $23,5 \%$ sehingga persentasenya mencapai $100 \%$. Nilai rata-rata kelas pada kondisi awal adalah 70 , pada siklus I meningkat 10,6 menjadi 80,6. Pada siklus II meningkat menjadi 90,6. Berdasarkan hasil penelitian menunjukkan bahwa penerapan metode Team Assisted Individualization (TAI) mata pelajaran matematika materi Persamaan Linear Dua Variabel dapat meningkatkan hasil belajar siswa kelas X-IPA SMA Methodist Banda Aceh tahun pelajaran 2018/2019.

Berdasarkan tindakan yang telah dilaksanakan, guru telah dapat mengubah suasana pembelajaran yang melibatkan siswa untuk aktif dalam proses pembelajaran dikelas sehingga mengakibatkan prestasi belajar siswa mengalami peningkatan. Penerapan metode kooperatif model TAI yang bertujuan mengubah suasana pembelajaran yang melibatkan siswa untuk aktif dalam kegiatan belajar mengajar dengan menggunakan presentasi kelas dan kelompok belajar siswa. Melalui belajar dari teman sebaya dan tentunya dibawah bimbingan guru, maka proses penerimaan dan pemahaman terhadap materi yang dipelajari akan semakin mudah dan cepat sehingga mereka termotivasi untuk mencari jawaban dengan cara berdiskusi dalam memecahkan masalah yang dihadapinya sehingga dapat meningkatkan partisipasi siswa, hal ini sesuai dengan Hanafiah (2009:65) yang mengatakan bahwa dengan adanya partisipasi siswa dalam pembelajaran akan memberikan peranan yang penting bagi keberhasilan tujuan dari proses pembelajaran yang terkait.

\section{KESIMPULAN}

Berdasarkan analisis data dan pembahasan hasil penelitian dapat disimpulkan bahwa hasil belajar siswa mata pelajaran matematika materi peluang dapat meningkat dan tuntas secara klasikal dengan menerapkan model pembelajaran Team 
Assisted Individualization (TAI) pada siswa kelas X-IPA SMA Methodist Badan Aceh tahun pelajaran 2018/2019. Hal ini dapat dilihat pada ketuntasan hasil belajar siswa secara klasikal pada kondisi awal adalah $58,8 \%$. Pada siklus I, ketuntasan siswa meningkat $17,7 \%$ dari sebelumnya sehingga mencapai 76,5\% sehingga ketuntasan belajar secara klasikal dapat dikatakan tidak tuntas. Pada siklus ke II terjadi peningkatan ke arah yang lebih baik lagi dan meningkat 23,5\% sehingga persentasenya mencapai $100 \%$.

Berdasarkan hasil penelitian, maka peneliti menyarankan agar guru sebaiknya memilih model pembelajaran matematika yang dapat meningkatkan keaktifan bagi peserta didik sehingga lebih mudah dalam memahami materi pelajaran, terutama dalam materi persamaan linear dua variabel. Untuk peneliti lainnya, perlu mengadakan penelitian-penelitian lebih lanjut terhadap pembelajaran menggunakan model pembelajaran kooperatif tipe TAI (Team Assisted Individualization) pada materi lainnya dalam mata pelajaran matematika.

\section{DAFTAR PUSTAKA}

Hamalik, Oemar. 2008. Strategi Belajar Mengajar. Jakarta: Bumi Aksara.

Hanafiah. 2009. Konsep Strategi Pembelajaran. Bandung: Refika Aditama.

Hardjodipuro. 2014. Penelitian Tindakan Kelas. Jakarta: Depdiknas.

Hermawan, H., Paloloang, B., \& Sukayasa, S. 2012. Penerapan model pembelajaran kooperatif tipe team assisted individualization (TAI) untuk meningkatkan hasil belajar siswa kelas V SDN 4 Bajugan pada operasi hitung campuran. Jurnal Kreatif Tadulako, 4(9), 44-59.
Hudoyo, Herman. 2006. Strategi Mengajar Belajar Matematika. Malang: IKIP Malang.

Ibrahim, Muslim. 2007. Pembelajaran Kooperatif. Surabaya: Universitas Negeri Malang.

Karim, K., \& Anshariyah, A. 2016. Penerapan Model Pembelajaran Kooperatif Tipe Team Assisted Individualization (TAI) untuk Melatih Kemampuan Pemecahan Masalah Matematis Siswa SMA. EDU-MAT, 4(1), 58-67.

Rahmawati, N. I. R., Yarmadi, Y., \& Zulkarnain, Z. 2017. Penggunaan Model Team Assisted Individualization Terhadap Hasil Belajar Geografi 2015/2016. JPG (Jurnal Penelitian Geografi), 5(1), $1-9$.

Sari, D. R., Masykuri, M., \& Mulyani, S. 2018. Penerapan Model Pembelajaran Kooperatif Team Assisted Individualization (TAI) Dilengkapi LKS untuk Meningkatkan Kemampuan Berpikir Kritis dan Prestasi Belajar Siswa pada Materi Kelarutan dan Hasil Kali Kelarutan Kelas XI IPA 3 SMA Negeri 2 Boyolali. Jurnal Pendidikan Kimia, 7(1), 12-18.

Sudjana, Nana. 2010. Penilaian Hasil Proses Belajar Mengajar. Bandung: Ramaja Rosdakarya.

Suyadi. 2012. Panduan Penelitian Tindakan Kelas. Yogyakarta: DIVA Press.

Yuwono, Ipung. 2005. Pembelajaran Matematika Secara Membumi. Malang: Universitas Negeri Malang. 